\title{
THE HIGH FEMALE AND HIGH MALE'S SIMILAR TALK STRATEGIES AMONG FEMALE TALK IN THE PATERNAL SOCIETY
}

\author{
Giyoto[1], Elen Inderasari[2], Lilik Untari[3]
}

\author{
[1]p.giyoto@gmail.com, [2]inderasari85iain@gmail.com,[3]nazala.suha@gmail.com \\ IAIN Surakarta \\ Sukoharjo, Central Java, Indonesia
}

\begin{abstract}
Islamic paternal parenting has socially patterned the man dominant language behavior over woman since childhood. This study explores the dominance distributions of high female and low female status in their informal talk strategy, the actual language use, among the students of The State Islamic Institute of Sur a kar ta in three functional topical units of conversations. The analysis technique was introduced by Sinclair and Coulthard (1975), for which Leech (1983) modifies the speech acts. The data implies that the talk strategy among Muslim females is relatively similar to th at of males. The higher female controls and initiates the interaction more while the lower is softer, more polite, more mutually supportive, and more cooperative to whomever she speaks to regardless of the status.
\end{abstract}

Keywords: Muslim female, act, move, talk strategy

\section{INTRODUCTION}

Javanese follows the paternal social paradigm in which, generally, the man controls and initiates more in their interaction in the cross or the same gender. It is said by Santoso (2012, p. 227) that Javanese society is a hierarchical paradigm which has a high distance between social level. It can be identified from the social units, such as family, firm or formal community, or state where the authority relations are characterized by paternalism or bapakism (fatherism). The bapak refers to the high social power, and as this address is the way to respect the superordinate from the subordinate anak buah (followers). The authority relations shape how the Javanese speak or use the language in their daily interactions. However, this will be gradually different depending on the speech situation or context they are involved in, the speaker's background, and the topic discussed. Accordingly, this study examines whether the high female has a similar conversational strategy with a high male in the Javanese paternal social paradigm among females. In male-to-male interaction, men compete to get more power until they are transparentabout who the superior and the inferior are. In maleto-female, men dominate the exchange to show and maintain their control (Giyoto, Novianni, \& Elen, 2020).

The speech community of Surakarta, Indonesia, is strongly correlated to the social layer based on gender role, reflected on the social convention of how to behave. Referring to the paternal society, the female shows her support and escort to the male part. Male has higher power and domination in their social structure when the community embraces the paternal social paradigm (Santoso, 2012). The gender role distinction is reflected in their talk strategy. Gender study always checks or identifies the participants' gender when interacting either in their internal or external speech community. These gender identities organize and control their ways of perceiving, interpreting, and the method of responding, including the ways of using the 
language or other actions. This social perception has been shaped by the family structure and its parentingamong gender at home, in which the mother recognizes how women and boys behave and speak. Family is the template of parenting used as the behavioral reference of the children in their social areas. Gender starts in childhood from the family environment, especially when their mother looks after the children closely before they have friends and socialize outside. Mother has introduced the distinctive norm and culture based on the children's sex since the pre-Oedipusperiod (Chodorow in Roman, Juhasz, \& Miller, 1994, pp. 134-151). It studies the general gender differences in the preoedipal period in parenting the sons and daughters, which is also relevant to Javanese's paternal society.

Chodorow also said that 'mothers are and have been the child's primary caretaker, socializer, and inner objects; fathers are secondary objects for boys and girls.' Mother treats and educates the daughters differently from the sons. Chodorow cited Deutsch's statement that the nature of the mother's engagement to the boys is different from girls". The boy's relationship with his mother focuses on ownership, competition issues, and sex understanding. The lesson of mother to her daughter focuses on its equality and togetherness, like playing doll beyond and the boys play car competition, game, and the other competitions.

Chodorow concluded that the daughter stays closer and longer than the boys in terms of emotion and space. The phase of the mother's engagement in the infant's period on the son is shorter than the daughter. Thus the mother's way of behaving influences more to the daughter. The process and type of relationship based on gender that has been educated by the mother continues to the time when they play and socialize in society. They play and interact socially with the same gender. Th is socialization model continues to form separated norms based on their gender. These norms, thus, are different for female s and males (Santoso, 2012). Adult women and men, then, may unwittingly bring different norms to their conversational strategy. The memberships of other communities ultimately shape the speakers' social world view, that is, how the local ized interactive process works (Gumperz \& Cook-Gumperz in Paulston, Bratt, Kiesling, \& Rangel, 2012, p. 67). Eckert \& Sally (2003, p. 5) explained that individual identity is based on a diversity of memberships in different practice communities. The memberships are expressed in how they use the language or his conversational tactics, including the membership of gender. These differences can be more incisive in the paternal social paradigm, as studied here.

The gender background of the speaker and its social role becomes the fir st consideration of the listener. Male and female speak differently in their use of particular conversational practices (Baker, 2008; Edvardsson, 2007; Gomaa, 2015; Holmgreen, 2009; Johnson \& Ensslin, 200 7; King, 2011; Thomberg, 2006; Yavuz, 2015; Yule, 2010). Thorne \& Henly (1975) have studied language use related to gender by using two different approaches: the Difference and the Dominance Approach. The difference Approach assumes that a woman has a distinct subculture from the man, which controls how she categorizes, organizes, views, and codes her world (Yavuz, 2015, p. 25). She has different knowledge, belief, and cognition process. This approach believes that gender has been sub-classified culturally and socially since their parenting ways. Parents treat their daughters differently from their son. The different treatments and cares of parenting lead to the other behaviors between woman and man.

Many studies clarify the three approaches from the gaps only, as done by the deficit approach (Lakoff, 1975) even though they can be more appropriate with the Dominance or Different Approach. Those can also be seen from the studies of Edvardsson and Thomberg (Edvardsson, 2007; Thomberg, 2006). Due to the overlaps of the Female Deficit Approach to the other two approaches, this approach is not used as much as the other ones, as said by (Coates, 2004, p.7) that '... except for the deficit perspective, are still thriving and contributing to the gender-based research on 
language...'. However, the Dominance Approach and Difference Approach may have the same gaps or form of differences. The problem, then, is which suitable approach is and what aspects to consider are. Deciding the appropriate approach for analyzing the gender conflicts involves the other elements as well, not only the rising phenomenon of the different behaviors but also the type of society (paternal or maternal) and the conflicts' solution (domination and tolerance). Finally, it is proposed three aspects in deciding the appropriate approach for analyzing the gender gaps: the type of the society, the form of the conflict, and the conflict's solution.

Referring to society's type, the Difference Approach can be more appropriate to the non-paternal and nonmaternal social paradigm in which the genders have equal treatment or relatively separated norms. This example can be seen in India, in which, at the first start, the Karibian language was used by the male. In contrast, the Arawak language, as the vernacular language, was used by females. The social norm of females was the native norm, and the male norm was of Karibian norm, due to the male soldiers married the local females. The community treats the mother, followed by her daughter, to speak the vernacular language while the father, followed by his son, speaks Karibian. This community has two different ways of interaction and culture. There are two norms of using language between the community's males and females, having two subcultures. The Difference Approach should explain the different ways and values of the language used between man and woman. They have different ways of talking due to other cultural attributes even though man dominates women as proposed by the Dominance Approach (West \& Zimmermanin Coates, 2004, p. 115). Every woman brings her identity or attribute of culture in her daily interaction, including using the language, mainly in her talk strategy. This attribute shows her speech community memberships, as Coates $(2004$, p. 6) stated. A critic of this approach is that most people interact on an equal basis. Women are not always victims of linguistic oppression, as confirmed by the constructivism approach and difference approach in gender studies.

Finally, the difference approach is not appropriate for the Javanese speech community, which applies the powerbased-interaction as a paternal society. Javanese treats the man to be more powerful biologically, culturally, and socially; and finally leading to the paternal based paradigm. Thus, the Javanese community's social behavior is more appropriate to the Dominance Approach (Henly \& Kramarae in Roman, Juhasz, \& Miller, 1994). The different ways of life, perceiving, and responding are the effects or impact of man and woman's different power. Parents treat their kid differently in power and teach to fight for control instead of fulfilling the demand of culture only. Javanese, which holds the paternal gendered difference basis, will solve the problem or conflict between gender gaps based on the power, not the right of equality but gendered power difference. Accordingly, the starting essence is the more power attributed to man; he has a different culture that creates deficit ways of behaving. This power-based-gender difference creates ways of interacting and behaving, including using the language discussed by Female Deficit, which views the general gaps, not from the fundamental concept of social norm and stronger biological belongings. Nyamekye \& Yarney (2015) studied woman behavior in Yendi Northern Gana, which is monitored and controlled by men, either the men are of family or other relations". Women cannot be away from being a housewife who serve and responsible for the family daily need as well as household activities. Edvardsson (2007), stated in his research about topic change and initiation based on gender in topic change among student's conversation of English as a second language, found that men produced topic twice more than women".

The characteristics of the Dominance Approach can be traced into 1) the type of the society (paternal/maternal dominance), 2 ) gaps (woman's deficit language use and her second social role), and 3) solution of gaps (dominating or empathy); while the 
characteristics of Difference Approach comes into 1) Type is two gender-sided society, 2) gaps is the domination of certain gender, and 3) solution of the gaps is equality or understanding another cultural gender role. The example is of Javanese, including Surakarta, which has the source of problems is the paternal gender-based community, in which: the problem is triggered by the absence of man's tolerance and rejects of man's power, the gaps can be solved by the authority in which the man still claim and operate the power-based norm or by empathy in which the man does not utilize his power to perceive the conflict, but neglecting the power of respecting the low. It is the reason why the dominant approach is proper to use in analyzing the gender gaps among the students in Surakarta, Indonesia.

\section{METHOD}

The Data was randomly taken from the recorded survey of female participants of all the faculties. The researcher analyzed the speaker's talk strategy based on the gender role using discourse analysis of Birmingham Discourse Analysis Model (Sinclair \& Coulthrad, 1975) that emphasizes the hierarchy of spoken interaction: transaction, turn, exchange, move, and act. The transaction is the conversational interaction activity among the female students composed of one or more exchanges. Exchange is a pair of at least two turns by two different participants (Part). Turn is composed of one or more moves. The move covers the speech activity for initiating (In), responding (Res), and following up (Fol) the preceding speech. One or more acts form the move. The act covers a speech function, the smallest unit of the transaction used as the basic unit to analyze. Act refers to verb groups of speech acts formulated by (Leech, 1983). Leech classifies speech acts based on each act's distinctive component analysis, making the result more applicable, accurate, and measurable. The following components are used in classifying the acts: 1) does the event happen after the speaker's act? 2) is the speaker or the listener involved in that event?; 3) if the event happens after the speaker's act, is it compulsory to the listener or not?; 4) does the event give the benefit to the speaker? and; 5) what attitude implies?. The act implications are classified into five types in terms of its attitude: a) assertive (A), b) directive (D), c) commissive (C), d) expressive (E); e) rogative (R).

\section{RESULTS AND DISCUSSION \\ Female-to-Female Conversational Strategy at Informal Situation in Shariah and Islamic Economics Faculty (SIEF) The Description of Topic, Role Relationship, Context, and Conversational Setting \\ The conversation happened} informally when female students of SIEF Faculty have a course break. The students usually stay in a group, having an informal conversation after getting a lecture and waiting for the next class. It happened in the building of SIEF, where they had a lecture. Therefore, this setting of the place has been familiar to the participants. In this informal conversation, there are five female participants, students of the seventh semester of SIEF. The topic was about friendship, talking about the condition of one of the participants who was sick. They were classmates. F2 was the participant who had a big influence in this conversation, so she was assumed to have higher status among others in this conversation. F3 was a classmate of all participants that had ever had the same illness as F1. F4 and F5 was the classmate of F3. They were close friends.

The Transaction Data on Female Conversation in Informal Situation of SIEF Faculty

\begin{tabular}{lllll} 
Part & \multicolumn{1}{c}{ Transaction } & Act Type & No. & Move \\
\hline F1 & $\begin{array}{l}\text { Piye mbak piye mbakngana(0,5) ara mudeng aku, aku } \\
\text { ngana. } \\
\text { "How is it miss? I don't understand" }\end{array}$ & Inquire & 1 & Initiation
\end{tabular}




\begin{tabular}{|c|c|c|c|c|}
\hline F3+ & $\begin{array}{l}\text { Ko.. kowe ngapa mangan kaya ngunu [barang?] } \\
\text { "What are doing? You drink that thing" }\end{array}$ & Ask & 2 & Response \\
\hline F1 & $\begin{array}{l}\text { [Ngombe] obat. } \\
\text { "Drinking medicine" }\end{array}$ & Answer & 3 & Initiation \\
\hline $\mathrm{F} 2$ & $\begin{array}{l}\text { E:::angeti } \\
\text { "E::: this is warm" }\end{array}$ & Assert & 4 & Response \\
\hline F3+ & $\begin{array}{l}\text { EMANG LARAApA? } \\
\text { "what sickness?" }\end{array}$ & Ask & 5 & Initiation \\
\hline F1 & $\begin{array}{l}\text { Panas kuwi } \\
\text { "That is cold" }\end{array}$ & Answer & 6 & Response \\
\hline $\mathrm{F} 2$ & $\begin{array}{l}\text { Anget. } \\
\text { "Warm" }\end{array}$ & Assert & 7 & Follow-up \\
\hline F3+ & $\begin{array}{l}\text { Lara apa?wis, akura nduwe nomere. } \\
\text { "what sickness, I don't have his (phone) number" }\end{array}$ & $\begin{array}{l}\text { Commisera } \\
\text { te }\end{array}$ & 8 & Initiation \\
\hline F1 & $\begin{array}{l}\text { Lara lapa.hehehe.aku::: ((laughing)) } \\
\text { "I am broken heart" }\end{array}$ & Announce & 9 & Response \\
\hline F3+ & $\begin{array}{l}\text { Lara ati:::i((laughing)) Laraati diParame:::exe } \\
\text { "Broken heart by Paramex" }\end{array}$ & Assert & 10 & Follow-up \\
\hline F1 & $\begin{array}{l}\text { Ora:::a saiki modele Tolak Angin. } \\
\text { "No, now is the era of Tolak Angin" }\end{array}$ & Announce & 11 & Initiation \\
\hline \multirow[t]{4}{*}{ F3+ } & Kawe thek melu-melu aku. & $\begin{array}{l}\text { Commisera } \\
\text { te }\end{array}$ & 12 & \\
\hline & $\begin{array}{l}\text { Aaah, kawe ki ngapa, kawe ki ngapa? } \\
\text { "why do you follow me, what are you doing?" }\end{array}$ & Ask & 13 & Response \\
\hline & $\begin{array}{l}\text { He KAWE KAK MELU-MELU AKU? } \\
\text { "He why are you hanger on me?" }\end{array}$ & Ask & 14 & \\
\hline & $\begin{array}{l}\text { Kemakan iklan pa? } \\
\text { "Are you influenced by ads?" }\end{array}$ & Inquire & 15 & Initiation \\
\hline F1 & $\begin{array}{l}\text { Eh eh eh, aku melu-meluTV, ora melu-melu kawe } \\
\text { kak'e::: } \\
\text { "eh eh eh I am following TV notyou" }\end{array}$ & Answer & 16 & Response \\
\hline $\mathrm{F} 2$ & $\begin{array}{l}\text { Eeeeeh, aku mau lho mau lho:::aku mau:::Iho ((loo king } \\
\text { at the food brought by F3+)) } \\
\text { "eh, I want that" }\end{array}$ & Aks for & 17 & Initiation \\
\hline $\mathrm{F} 1$ & $\begin{array}{l}\text { Eeee:::emang siapa elo? } \\
\text { "Eeee, Who are you?" }\end{array}$ & Boast & 18 & Response \\
\hline $\mathrm{F} 2$ & $\begin{array}{l}\text { Aku mau::: u Iho:::o aku mau Iho:::o Go Rene go rene go } \\
\text { rene! } \\
\text { "I want, pass it here" }\end{array}$ & Ask for & 19 & Initiation \\
\hline F1 & $\begin{array}{l}\text { Aja sik. Iki di guwak } \\
\text { "No, this is discarded" }\end{array}$ & Suggest & 20 & Response \\
\hline F3+ & $\begin{array}{l}=\text { Iki nggonesapa iki? ((eating)) } \\
\text { "Whose is this?" }\end{array}$ & Ask & 21 & Initiation \\
\hline F4 & $\begin{array}{l}\text { Orangerti } \\
\text { "Idon't know" }\end{array}$ & Answer & 22 & Response \\
\hline F1 & $\begin{array}{l}\text { Sik dilitdilit } \\
\text { "Waita minute" }\end{array}$ & Command & 23 & Initiation \\
\hline F4 & $\begin{array}{l}\text { Nggone Ririn sing enek coklate } \\
\text { "Ririn's is that with chocolate" }\end{array}$ & Announce & 24 & Response \\
\hline $\mathrm{F} 1$ & $\begin{array}{l}\text { Tak ngombe obatsik } \\
\text { "Let me have medicine first" }\end{array}$ & $\begin{array}{l}\text { Beg/reque } \\
\text { st }\end{array}$ & 25 & Initiation \\
\hline $\mathrm{F} 2$ & $\begin{array}{l}\text { Kuwi jenenge ra obat } \\
\text { "That is not called medicine" }\end{array}$ & Boast & 26 & Response \\
\hline F3+ & $\begin{array}{l}\text { Permen } \\
\text { "Sweets" }\end{array}$ & Assert & 27 & Follow-up \\
\hline $\mathrm{F} 2$ & $\begin{array}{l}\text { Aku biasaneseneng permen sing ngene iki lho } \\
\text { "Usually Ilike such a kind of sweets" }\end{array}$ & Announce & 28 & Initiation \\
\hline $\mathrm{F} 4$ & Hek, rasane we ora enakog & Announce & 29 & Response \\
\hline
\end{tabular}




\begin{tabular}{|c|c|c|c|c|}
\hline $\mathrm{F} 2$ & $\begin{array}{l}\text { "It does not taste good" } \\
=\text { Ena:::ak? } \\
\text { "Nice" }\end{array}$ & Ask & 30 & Initiation \\
\hline $\mathrm{F} 4$ & $\begin{array}{l}\text { Tak dol lho iki } \\
\text { "I sell this, you know" }\end{array}$ & Assert & 31 & Response \\
\hline $\mathrm{F} 2$ & $\begin{array}{l}\text { Enak Rin? } \\
\text { "is it nice, Rin? }\end{array}$ & Ask & 32 & Initiation \\
\hline $\mathrm{F} 1$ & $\begin{array}{l}\text { Enak banget, hoiiik ((by tonguing out)) } \\
\text { "Very nice" }\end{array}$ & Answer & 33 & Response \\
\hline F2 & $\begin{array}{l}\text { Ahaha ((laughing)) } \\
\text { "Ha ha" }\end{array}$ & Assert & 34 & Follow-up \\
\hline F3+ & $\begin{array}{l}\text { Kawe gene to Rin? } \\
\text { "What is wrong with you Rin?" }\end{array}$ & Ask & 35 & Initiation \\
\hline $\mathrm{F} 1$ & $\begin{array}{l}\text { Awakku gemrebeg gem ge gedembredeg bada nge-date } \\
\text { "I get cold after dating" }\end{array}$ & Answer & 36 & Response \\
\hline $\mathrm{F} 2$ & $\begin{array}{l}=\text { Opo kuwi:.:i ((laughing)) } \\
\text { "What is that" }\end{array}$ & Ask & 37 & Initiation \\
\hline $\mathrm{F} 1$ & $\begin{array}{l}\text { Gedembredeg badangedet bada ngedet } \\
\text { "I get cold after dating" }\end{array}$ & Answer & 38 & Response \\
\hline F2 & $\begin{array}{l}\text { Malu-malu kucing, Cimon malu-malu kuci:::ing } \\
\text { "Bashful” }\end{array}$ & Announce & 39 & Follow-up \\
\hline $\mathrm{F} 1$ & $\begin{array}{l}\text { Kodo wedi e:::e kodo wede ibusadah Badahadasadah } \\
\text { "Should be afraid" }\end{array}$ & Announce & 40 & Initiation \\
\hline F2 & $\begin{array}{l}\text { Aku ra mu den:::ng aku ra mudeng aku ra muden:::ng } \\
\text { "I don't understand" }\end{array}$ & Assert & 41 & Response \\
\hline F1 & $\begin{array}{l}\text { Kodo kidi kodo wodo rada } \\
\text { "((meaningless expression })) "\end{array}$ & Announce & 42 & Initiation \\
\hline F3+ & $\begin{array}{l}\text { Do ngomong ngunu ki } \\
\text { "some people say this way" }\end{array}$ & Inquire & 43 & Response \\
\hline $\mathrm{F} 2$ & $\begin{array}{l}\text { Aku ra muden:::ng } \\
\text { "I dn't understand" }\end{array}$ & Announce & 44 & Follow-up \\
\hline F3+ & $\begin{array}{l}\text { Sak apa jare iso basa Jerman akhire ngunu kuwiguran } \\
\text { "Since she can speak Germany, but apparently not too } \\
\text { well" }\end{array}$ & Boast & 45 & Initiation \\
\hline $\mathrm{F} 1$ & $\begin{array}{l}\text { Ehe:::ei:::I } \\
\text { "Ehe" }\end{array}$ & Assert & 46 & Response \\
\hline $\mathrm{F} 2$ & $\begin{array}{l}\text { Aku ra muden::::::ng. } \\
\text { "I don't understand" }\end{array}$ & Assert & 47 & Follow-up \\
\hline
\end{tabular}

Table 1. Analysis of Act and Move Frequency of SIEF Faculty

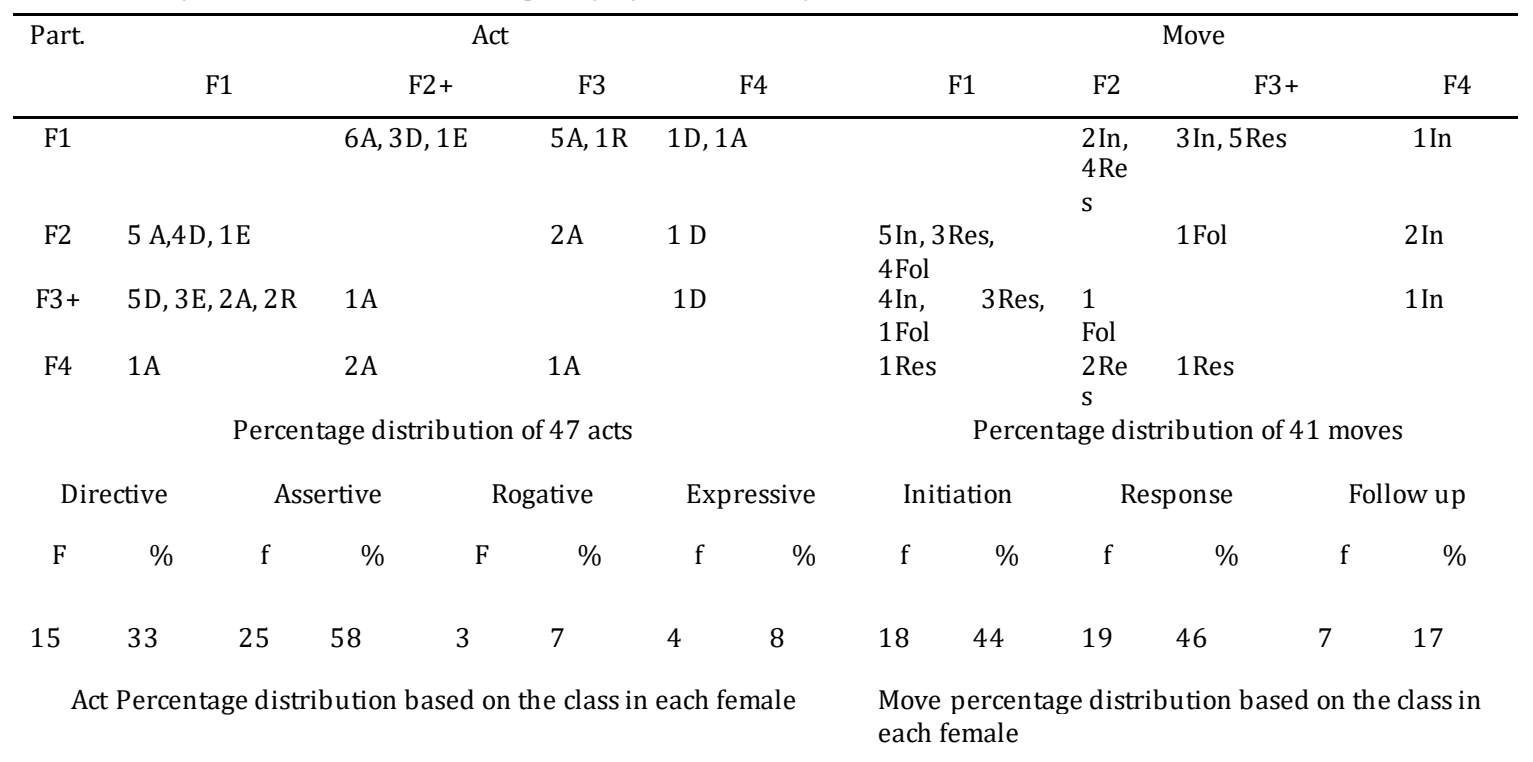




$\begin{array}{llllllllllllll}\mathrm{F} 1+ & \mathrm{F} 2 & \mathrm{~F} 1+ & \mathrm{F} 2 & \mathrm{~F} 1+ & \mathrm{F} 2 & \mathrm{~F} 1+ & \mathrm{F} 2 & \mathrm{~F} 1+ & \mathrm{F} 2 & \mathrm{~F} 1+ & \mathrm{F} 2 & \mathrm{~F} 1+ & \mathrm{F} 2 \\ & & & & & & & & & & & & & \\ 6 / 1 & (9 / 4) & 3 / 2 & (23 / 4) & 2 / 3 & (1 / 4) / & 2 / 4 & (2 / 4) & 5 / 1 & (13 / 4 & 3 / 1 & (16 / 4) / & 2 / 7 & (5 / 4) / \\ 5 & / 15 & 5 & / 25 & & 3 & & / 4 & 8 & ) / 18 & 9 & 19 & 7 \\ 50 \% & 15 \% & 17 \% & 22 \% & 67 \% & 9 \% & 50 \% & 16 \% & 28 \% & 18 \% & 16 \% & 21 \% & 29 \% & 18 \%\end{array}$

\section{Data Interpretation of SIEF Faculty}

Based on the distribution of the whole acts in this functional topical unit of this faculty, the interesting one is that in informal and closed feeling conversation: 1 ) the higher status female dominates most of the acts are directive (50\%) among all kinds of acts, including rogative, expressive; and also dominates the move of initiation $(28 \%$ vs. $18 \%$ ) and follow up (29\% vs. $18 \%) ; 2$ ) The lower dominates only the acts of assertive (22\% vs. $17 \%)$ and the move of response $(21 \%$ vs. $16 \%)$. It seems that the participant who makes more directive acts, which is approximately double, will make more moves of initiations as well. The participant who makes more assertive acts will make more moves of responses. This fact implies the social meaning that: 1 ) the higher status female tends to dominate the lower status female in informal and closed conversation in which the higher female make her listener do something by making more directive acts, as competition play in winning which one is the superior: 2) she has good affection to the listeners by having dominant expressive acts; and 3) she controls the conversation by initiation and follow up; 4) the lowers support and accommodate the higher by asserting and responding. It infers that this informal female-to-female conversation does not match the findings of female strategies in formal cross-gender interaction. The female tends to have less directive and initiation. In informal female-to-female conversation, the higher female has the same strategy as the higher male in formal cross-gender conversation (Giyoto, 2013).

\section{Female-to-Female Conversational Strategy at Informal Situation of Ushuluddin and Dakwah Faculty (UDF) The Topic, Role Relationship, Context, and ConversationalSetting}

The conversation happened informally in one of the rooms of the female dormitory around IAIN Surakarta. At that moment, F2 was ironing her clothes in the room while F3 was studying. Suddenly, F1 came from campus and directly discussed Boy Scout and the scholarship that she got. The informal topic was conducted by comparing UDF and other faculties. The conversation involved three female participants. F1 was a seventh-semester student who got the Tahfid Al Qur'an scholarship, and F2 was the ninth semester student who was doing her thesis. She did not join any extracurricular on campus. Meanwhile, F3 was the ninth semester student in the UDF faculty. F3 did not join any extracurricularas well.

Nevertheless, F3 was a teacher of Preschool in Boyolali. F3, F2, F1 were roommates. F2 was assumed to have a higher status because she was in the ninth semester and doing her thesis.

\section{The Transaction Data on Female Conversation in Informal Situation of UDF Faculty}

\begin{tabular}{|c|c|c|c|c|}
\hline $\mathbf{Z}$ & Transaction & Act Type & No. & Move \\
\hline F1 & $\begin{array}{l}\text { Mbak Endang tau nggak si:::ih? Kan itu ya di } \\
\text { kampusitu kanada UKM Racana mbakya? } \\
\text { "Miss Endang, there is student activity unit } \\
\text { Racana, isn'tit?" }\end{array}$ & Inquire & 1 & Initiation \\
\hline $\mathrm{F} 2+$ & $\begin{array}{l}\text { Aku ra ngerti kok mbak, aku ra wong organisasi } \\
\text { kok } \\
\text { "I don't know Miss, I am not activist" }\end{array}$ & Announce & 2 & Response \\
\hline $\mathrm{F} 1$ & $\begin{array}{l}\text { A:::ah, mbak Endang masaknggak tau racana:::a, } \\
\text { pramuka itu lhoo mba::ak } \\
\text { "Ah, it is not believable Miss Endang Does not }\end{array}$ & Inquire & 3 & Initiation \\
\hline
\end{tabular}


know, it boy scouts miss"

$\mathrm{F} 2+\quad$ o:::o yo, trus?

"O, so?"

F1 Lha pramuka itu, tau nggaksih (0.5) itu tuh yang nguasain anak ushuludin tau:::uk

"The boy scouts controls the Ushluddin students, you know"

$\mathrm{F} 2+\quad$ E:::emang ushuludinisohpramuka

"Are you sure Ushuluddin students are good scouts"

F1 Eh mbakjangan salah yah(0.5) anak usuludin kan kebanyakan anak Gontor nah di Gontor itu pramuka tu mbak udahnyam:::mpe ke luar negeri "Miss, don't be wrong, Most of Ushuluddin students are from Gontor of which its students go internationally"

F3 Sampeyan lulusan Gontor to mbak?

"Were you graduated from Gaontor Miss?"

Ask

Response

Announce

$5 \quad$ Follow-up

Boast

6 Initiation

Announce

$7 \quad$ Response

F1 Iya:::a mbak, aku anaknya Gontor (0.5) kan dulu aku muridnya pak Hasan Kyai Haji Hasan Abdullah Sahal itu (0.5) salah satu dari tri murti Gontor mba:::ak jadi aku PA:::Aham banget seluk beluknya Gontor

"Yes I was, I was a student of Kyai Haji Hasan Abdullah Sahal, one of the three founders of Gontor Boarding School. I was the academic consultant so I knew any detail of Gontor"

F2+ Huum(0.5) bapakejugaalumni [Gonto] kok "Yes, his father was also alumni of Gontor"

F1 [Huum], bapak ku juga kebetulan alumni Gontor dan ketua IKPM Gontor dan temen-temenku ba:::nyak banget yang di Gontor (0.5) sekarang ketemu:::u la::: gi ma orangorang Gontor di ushuludin tapinggak papa de:::h asik kokmerekA

"My father was Gontor Alumni and the head of IKPM, and I have may friends of Gontor in Ushuluddin. It is okay, they are nice"

F3 Aku juga punya temen Usuluddin kok mbak (0.5) tapi dah luLUS

Ask

8 Initiation

Answer

9 Response

Assert

10 Initiation

Assert

11 Response

"I have a friend of Gontor also Miss, but graduated already"

F1 Tapi kayaknya bukandari [Gontor] deh mbak

\section{Gontorsatu}

[Gontor] mba:::ak

"Gontor Miss, one"

F1 Siapa na:::anya:::a?

"What is her name?"

F3 jangan sebut merk Putralho [mbak],

"Don't mention the brand, He is boy"

F1

kenal deh mbak

[Kayak]

"It seems I know

Miss"

Mas siapa namanya:::a?

"Mr, what is his name?"

$\mathrm{F} 2+\quad$ Faiz

"Faiz"
Announce

Initiation

Inquire

13 Response

Announce

14

Initiation

Ask

Response

Answer

16 Initiation

Announce

17

Response

Inquire

Initiation

Announce

Response 


\begin{tabular}{|c|c|c|c|c|}
\hline F3 & $\begin{array}{l}\text { OIYO (0.5), ha'a kae } \\
\text { "Yes, That one" }\end{array}$ & Assert & 20 & Follow-up \\
\hline F1 & $\begin{array}{l}\text { Ha'a kan, aku di Racana ma kak Nayla } \\
\text { "Yes he is, you know I am in Racana with Miss } \\
\text { Nayla" }\end{array}$ & Assert & 21 & Initiation \\
\hline F3 & $\begin{array}{l}\text { Ha'a mbak ikumbak } \\
\text { "That is right" }\end{array}$ & Assert & 22 & Response \\
\hline F1 & $\begin{array}{l}\text { Ha'a aku di Racana kui ketemune ternyata [di (0.5)] } \\
\text { "Ha ha, I met him in Racana" }\end{array}$ & Assert & 23 & Initiation \\
\hline F3 & $\begin{array}{l}{[\text { Gontor satu] }} \\
{[\text { Gontor one] }}\end{array}$ & Announce & 24 & Response \\
\hline $\mathrm{F} 1$ & $\begin{array}{l}\text { Ha'a ternyata disini tu (0.5) e apa pasca Sarjananya } \\
\text { ada Ushuluddin juga YAH? } \\
\text { "Yes, unpredictably, there is also post graduate } \\
\text { program of Ushuluddin, isn'tit" }\end{array}$ & Inquire & 25 & Initiation \\
\hline F3 & $\begin{array}{l}\text { Ono tafsir hadist } \\
\text { "Yes, Tafsir Hadis" }\end{array}$ & Announce & 26 & Response \\
\hline F1 & $\begin{array}{l}\text { Aku takutnya nanti S2 nya sama bapak gimana:::a } \\
\text { ushuluddinnya ihhh nggak banget deh mbak } \\
\text { "I am afraid my post graduate with Father, I think } \\
\text { it is not very nice Miss" }\end{array}$ & Inquire & 27 & Initiation \\
\hline F2+ & $\begin{array}{l}\text { Yo ra popo lah } \\
\text { "It is okey" }\end{array}$ & Suggest & 28 & Response \\
\hline $\mathrm{F} 1$ & $\begin{array}{l}\text { Masak aku tua diSolo (0.5) tapi pengen ke Mesi::: ir } \\
\text { atau nggak ke Mekah mba:::ak } \\
\text { "Should I get old in Solo, I want to go to Egypt or } \\
\text { Mecca" }\end{array}$ & Announce & 29 & Initiation \\
\hline F3 & $\begin{array}{l}\text { Dari pada tua nang Mekah mending tua nang kene } \\
\text { haha } \\
\text { "It is better getting old here than Mecca" }\end{array}$ & Suggest & 30 & Response \\
\hline $\mathrm{F} 1$ & $\begin{array}{l}\text { Ndak apa apa mbak, aku pengen mencari (0.5) } \\
\text { pengalamanapa,lain aja mba:::ak } \\
\text { "It is okey Miss, I just want to have different } \\
\text { experience" }\end{array}$ & Announce & 31 & Initiation \\
\hline F2+ & $\begin{array}{l}\text { Eh mbak nggolek beasiswa ushuludin ki akeh } \\
\text { peluang beasiswane }\end{array}$ & Suggest & 32 & Response \\
\hline F1 & $\begin{array}{l}\text { Ya makannya mba:::ak, ayo cariin aku job untuk } \\
\text { keluar mba:::ak. }\end{array}$ & Command & 33 & Initiation \\
\hline F2+ & $\begin{array}{l}\text { "So that is why, find a job for me to go out Miss" } \\
\text { La kuk malah kon golekne. } \\
\text { "why you ask me to find for you" }\end{array}$ & Inquire & 34 & Response \\
\hline $\mathrm{F} 1$ & $\begin{array}{l}\text { La siapa tau aku banyak temen,(0.5)adikku juga } \\
\text { mau ke [Mekah] (0.5) jadi aku disa na udah ada } \\
\text { muhri:::im. } \\
\text { "Who knows I have a lot of friends, my brother } \\
\text { wants to go to Mecca, so I have already family } \\
\text { there" }\end{array}$ & Announce & 35 & Follow-up \\
\hline F3 & $\begin{array}{l}\text { [Tapi ushu]luddin S2 ne akeh sing neng kene lo } \\
\text { mbak } \\
\text { "But, There are many programs of Ushuluddin also } \\
\text { here Miss" }\end{array}$ & Announce & 36 & Initiation \\
\hline F1 & $\begin{array}{l}\text { Yo mbak yo } \\
\text { "Yes, you are right" }\end{array}$ & Assert & 37 & Response \\
\hline $\mathrm{F} 2+$ & $\begin{array}{l}\text { Biasane entuk beasiswa ko kene okyo? } \\
\text { "Usually, there is scholarship, isn'tit?" }\end{array}$ & Inquire & 38 & Initiation \\
\hline F1 & $\begin{array}{l}\text { He'e } \\
\text { "Yes" }\end{array}$ & Assert & 39 & Response \\
\hline F3 & $\begin{array}{l}\text { Mas sapa kae mbak? mas ajiz kuwi (0.5) cumlaude } \\
\text { to(0.5 trus etuk beasiswa mas antok kuwi beasiswa }\end{array}$ & Inquire & 40 & Initiation \\
\hline
\end{tabular}


mboh ora tapi S2 kene

"Mr. Ajiz was cumlaude and got scholarship, but I don't know whether Mr. Antok an awardee or not, but he is taking post graduate"

F1 Danyang palingitulho mbA:::Ak, ushuludin mau belajar ntar aku juga apa, skripsi terbaikya selama ini eh skripsi terbaik, mahasiswa terbaik ya? Pokoknya denger-denger tu kalo (0.5) usuludin skripsinya terbaik

"The students of Ushuluddin is always the best thesis writer so far"

F3 Skripsi terbaik

"The best Thesis"

F1 Enggak usuludin tu tiap taunnya (0.5) pasti mendudukipokoknya adayang the best terus la h diantara darise IAIN inigitu lho makanya kamu tu bangga jadi anak ushuludin katanya karena jurusan yang paling langka mbak trus apa namanya (0.5)

"Ushuluddin has the best position, even only one aspect. You should be pride of being here, it is rare program"

F2+ Yo aluse langka, hahahahahneng kasaregakeneng peminate

"The nice word is rare, but the hard one is that there is no much interest for new student candidates"

F1 Bagini mbakbukangak enek peminate! sekarang tu orang-orang terbalik ya mbakya? jaman moderen. Modernisasi dimana-mana ya mbak YA:::A orang itu dah pada ya melenceng lah dari agama tu melencenglah dari agama, dah banyak

"It is no much interest but people now have upside thinking, modern era. Modern era make many people deviate from the religion"

F2+ Berhubung da agama dah kayak gitu. Kudune Ushuluddintu punya, harus memiliki daya inovatif gen punya daya tarik yang berbeDA:::A

"Relating to religious study program, Ushuluddin should have a distinct and innovative strength"

F1 Nahitu dia mbak

"That is the problem"

F2+ Mosok kalah ma Tarbiyah, padahal Tarbiyah itu kan paling opo. Paling gampang pelajarane, nggak mikiryo mikirjuga

"It is unbelievable that Tarbiyah wins, just Tarbiyah, not needs too much thinking"

F1 Siapa bilang?

"Who syas?"

F2+ Yo mikir juga. Ning nggak koyo Ushuludin sing memang mikiragama

"It needs thinking also but it not the same as Ushuluddin which studies much about religion"

F1 Lulusan kalahdalam halapa itu mbak? "In what aspect do graduates loose?"

$\mathrm{F} 2+\quad$ Dalam penerimaanmuRI:::ID

"in students recruitment"

F1 Ohh dalam penerimaan murid nah itu dia mbak "Ohh, that is the problem"
Inquire

Response

Assert

Initiation

Announce

Response

Boast

Initiation

Announce

Response

Recommend 46 Initiation

Assert

Response

Boast

Initiation

Ask

Response

Assert

50 Follow-up

Ask

51 Initiation

Announce

52

Response

Assert

Follow-up 
F2+

Lha makanya

"That is why"

F1 Denger dulu MBA:::AK, aku mau ngomo:::ong Gini lho mbak (0.5) kata orang-orangitu kenapa nggak mau nggak mau di Ushuludin karena sekarangliat aja zaman semakin lama semakin edan ya $\mathrm{nggak}$ sih? nah terus (0.5) orang-orang tu-

"Listen to me, Miss. I want to say that many people do not want Ushuluddin because now is crazy era, then people-"

F2+ Orang-orangnyajuga [edan]

"Its people as well"

F1

[Nggak]. Nggak edan karna aku dah tersesat pada jalan yang luRUS orang-orang ushuludin itu mbak. bukan tersesat pada jalan yang sesat karena sekarang itu ya perkembangan zaman itu harus disertai dengan pengetahuan-pengetahuan agama (0.5), NAH kebanyakan orangitu kenapa mereka nggak mau ke Ushuludinnggak mau ini, maunya ke tarbiah lah ke ekonomi karena tak hanya mencari, mengejar semua di dunia iniya keduniA:::AN

"Not crazy, but I am guided to the right way in Ushuluddin, not lost in the wrong way in the wrong era. Now-life should be with the religion knowledge. Why many people do not do this because they are worldly oriented, not only looking for but also hunting"

$\mathrm{F} 2+\quad$ Ya makane mbak. ushuludin isoh nggawe inovatif liyo to, kan ushuludin wis ngerti nek masa la he kui .Yo kudune bisa mengatasi itulho mbak

"That is why Ushuluddin should be innovative to solve its problems"

F1 LHA sekarang kesadaran orang masing-masing mbak

"Now, it depends on one's awareness"

F2+ Kan iku tugas ushuludin tuk menyadarkan ORA:::ANG

"That is the job of Ushuluddin to make people aware"

F1 Nah sekarang kita liat basic dulu mbak kayak orang apa namanya dari luar pasti mereka dah takut duluan melihat, ah Ushuludin

"We see basically outsiders are afraid of Ushuluddin"

F2+ Nahjustru ituyang membuattidakmemilih karena Ushuludin sudah terkesan menakutkan, piye carane ben ushuludin kinggakmenakutkan

"Yes, that is the reason why people don't choose Ushluddin because it is scary, then find the way how to make it not scary"

F1 Tapi sebenarne nggakmenakutkan kokmbak biasa aja mbak

"Butactually it is nor scaring Miss, it is normal"

$\mathrm{F} 2+\quad$ Lha makanya inner-beautynya harus di keluarkan dari Ushuludin GITU LHO:::O

"so that Ushuluddin should generate the inner beauty, that one"
Assert

54 Initiation

Assert

55 Response

Boast

56 Initiation

Announce

57 Response

Assert

Initiation

Announce

Response

Recommend

60

Initiation

Announce

61

Response

Suggest

62

Initiation

Announce

63

Response

Suggest

64

Initiation 
Oo begitu jadi kita mbakEndang, saya pesen ma mbak Endang klo punya anak mending an dididi $k$ sejak dini:::i mbak Endang biar tertanam deh, katanya orang kalo dah tertanam di lingkungan pondok (0.5) kenapa ushuludin kebanya kan anak pondok (0.5) karena dia udah sepaham gitu lho mbak dari dia itu dipondokya udahkayakgini(0) jadi ketika dia mau kuliah meskipun kuliahnya bukan didalam pondok tapi dia tetep mencari komunitas yang dimana disitu tu banyak anakanak pondok termasuk anak ushuludin tersebut(0.5) gitu lho mbak.

"Oo that one Miss Endang, I suggest if Miss Endang has children you should educate much earlier to be internalised. It is said that when the children have been educated in Islamic boarding school they have the same thought. So when they are in university they look for boarding student community, including the students of Ushuluddin, that one Miss"

Table 2. Analysis of Act and Move Frequency of UDF Faculty

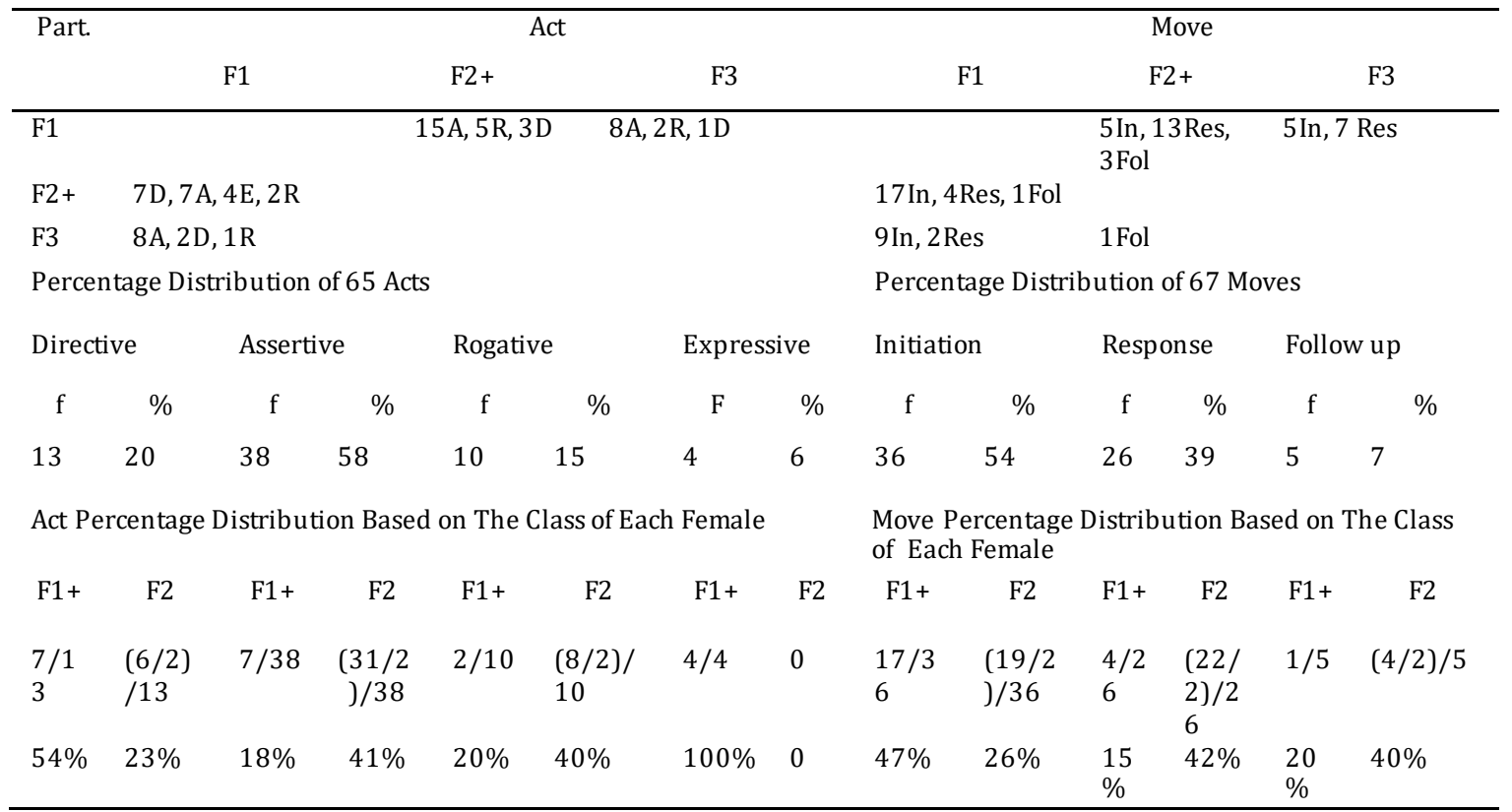

\section{Data Interpretation of UDF Faculty}

The functional topical unit takes a very long interaction for finishing the topic being discussed. The distribution of the acts and the move of females in this faculty is similar to those of females in SIEF Faculty, in which the whole acts are dominated by assertive (58\%), regarding that the femal es are enjoying togetherness and accommodativeness, in which only followed by the directive (20\%). The lower females dominate the acts of assertive around $41 \%$ each while the higher female dominates the directive acts around $54 \%$ but followed by expressive acts around $100 \%$ to soften her higher status. The higher also dominates the move of initiation around $47 \%$ and $26 \%$ of each lower female while the lower females dominate the move of response around $42 \%$ and $15 \%$ of the higher. Accordingly, the distribution shows that the participant who makes more directive acts will make more moves of initiations. The participant who makes more assertive acts will make more moves of responses. It 
means that the higher status female make s her listeners do something and initiate more in her conversation, the same as those of the higher female in cross-gender conversation. The difference is that the higher also dominates the expressive acts to cover her dominance. In most of their strategies, the lower females assert and respond, the higher whether informing their belief about something or telling what they know.

\section{Female-to-Female Conversational}

Strategy at Informal Situation of Islamic

Education and Language Faculty (IELF)

The Description of Topic, Role

Relationship, Context, and Conversational Setting

The place's setting was in a campus canteen in the morning, around 9 a.m. before attending the class. Two of the participants interacted informally while having lunch in the canteen area. The topic being discussed by the participants was about weird behavior, for instance, behavior that is often laughed at by them when they feel weird. The participants were female students of the same semester, one of which is much older. F1 is a female student, married, having two kids. F2 is still single and a classmate. F1 has a higher status than F2 based on the economic aspect and age. The two participants are classmates, although they have an age -gap. Therefore, F1 is socially assumed to have higher status than F2.

The Transaction Data on Female Conversation in Informal Situation of IELF Faculty

\begin{tabular}{|c|c|c|c|c|}
\hline Part & Transaction & Act Type & No. & Move \\
\hline $\mathrm{F} 1+$ & $\begin{array}{l}\text { Lucu:::u banget hari ini. Sebenarnya aku kalo ini } \\
\text { pengen nangis tapi aku ketawa. Ketawa aja di jalan. } \\
\text { Tapi itu bagus kokuntuk membelokkan perasaan, kan } \\
\text { sebenarnya sedih atoapaitubuatan manusia sendiri } \\
\text { karena Allah menciptakan perasaan yang tunduk } \\
\text { kepada-Nya gitu. Jadi Dia tidak mengolah perasaan } \\
\text { manusia= } \\
\text { "Today is very funny. Actually I want to cry but I laugh } \\
\text { along the street. But this is nice to turn the feeling. } \\
\text { Actually being happy or sad is created by human } \\
\text { themselves. Allah creates feeling that obeys } \\
\text { themselves. He doesn't manage human feeling" }\end{array}$ & Announce & 1 & Initiation \\
\hline F2 & $\begin{array}{l}=\text { He eh } \\
\text { "Yess" }\end{array}$ & Commiserate & 2 & Response \\
\hline $\mathrm{F} 1+$ & $\begin{array}{l}\text { Kita sendiriyang membuat. } \\
\text { "We, ourselves, create" }\end{array}$ & Assert & 3 & Initiation \\
\hline F2 & $\begin{array}{l}\text { He eh, he eh } \\
\text { "Hehe he" }\end{array}$ & Assert & 4 & Response \\
\hline $\mathrm{F} 1+$ & $\begin{array}{l}\text { Jadi aku belokkan sendiritadi ketawa-ketawa sendiri di } \\
\text { jalan }(0.5) \text { hehehe. Orang gila:: } \\
\text { "So I turned the feeling myself laughing along the way } \\
\text { like crazy man" }\end{array}$ & Announce & 5 & Initiation \\
\hline F2 & $\begin{array}{l}\text { Aku juga pernah kaya gitu mbak, ya kayagitu di jalan } \\
\text { tuya ketawa-ketawa sendiri-sendiri } \\
\text { "I have ever been that Miss, laughing myself along the } \\
\text { way" }\end{array}$ & Announce & 6 & Response \\
\hline & $\begin{array}{l}\text { yang ha:::a ini mau ke mana? } \\
\text { "Where I am going" }\end{array}$ & Inquire & 7 & \\
\hline $\mathrm{F} 1+$ & $\begin{array}{l}\text { Terus aku udah diomelin sana-sini. } \\
\text { "I was blamed anywhere" }\end{array}$ & Lament & 8 & Initiation \\
\hline F2 & $\begin{array}{l}\text { He eh ((nodding while listening)) } \\
\text { "He he" }\end{array}$ & Commiserate & 9 & Response \\
\hline
\end{tabular}


F1+ Nggak tau nih beberapa minggu ini aku kena omelan terus, nduk. Nggak siapa::a nggak siapa::a nggak siapa::a Engh-henh Aku lagi ini (0.5) kayaknya uda berbuat baik, tapi bener, tapi ternyata salah, gitulho. Jadi dibuat begitu. Engh.

“I don't know. In the last few weeks I was blamed by anyone. I have done my best but it was wrong. That is the way"

Table 3. Analysis of Act and Move Frequency of IELF Faculty

\begin{tabular}{|c|c|c|c|c|c|c|c|c|c|c|c|c|c|}
\hline \multirow{2}{*}{ Part } & \multicolumn{7}{|c|}{ Act } & \multicolumn{6}{|l|}{ Move } \\
\hline & \multicolumn{3}{|c|}{$\mathrm{F} 1$} & \multicolumn{4}{|c|}{$\mathrm{F} 2+$} & \multicolumn{3}{|l|}{$\mathrm{F} 1$} & \multicolumn{3}{|c|}{$\mathrm{F} 2+$} \\
\hline F1 & & & & \multicolumn{4}{|c|}{$3 \mathrm{~A}, 2 \mathrm{E}$} & & & & \multicolumn{3}{|c|}{$3 \mathrm{In}, 1 \mathrm{Fol}$} \\
\hline $\mathrm{F} 2+$ & \multicolumn{7}{|c|}{$2 \mathrm{~A}, 1 \mathrm{E}, 1 \mathrm{R}$} & \multicolumn{6}{|l|}{3 Res } \\
\hline \multicolumn{8}{|c|}{ Percentage distribution of nine acts } & \multicolumn{6}{|c|}{ Percentage distribution seven moves } \\
\hline \multicolumn{2}{|c|}{ Directive } & \multicolumn{2}{|c|}{ Assertive } & \multicolumn{2}{|c|}{ Rogative } & \multicolumn{2}{|c|}{ Expressive } & \multicolumn{2}{|c|}{ Initiation } & \multicolumn{2}{|c|}{ Response } & \multicolumn{2}{|c|}{ Follow up } \\
\hline $\mathrm{F}$ & $\%$ & $\mathrm{~F}$ & $\%$ & $\mathrm{~F}$ & $\%$ & $\mathrm{f}$ & $\%$ & $\mathrm{f}$ & $\%$ & $\mathrm{f}$ & $\%$ & $\mathrm{f}$ & $\%$ \\
\hline 0 & 0 & 2 & 22 & 1 & 11 & 6 & 67 & 3 & 43 & 3 & 43 & 1 & 12 \\
\hline \multicolumn{8}{|c|}{ Act percentage distribution based on the class in each female } & \multicolumn{6}{|c|}{$\begin{array}{l}\text { Move percentage distribution based on the class in each } \\
\text { female }\end{array}$} \\
\hline $\mathrm{F} 1+$ & $\mathrm{F} 2$ & $\mathrm{~F} 1+$ & F2 & $\mathrm{F} 1+$ & F2 & $\mathrm{F} 1+$ & F2 & $\mathrm{F} 1+$ & $\mathrm{F} 2$ & $\mathrm{~F} 1+$ & $\mathrm{F} 2$ & $\mathrm{~F} 1+$ & $\mathrm{F} 2$ \\
\hline 0 & 0 & 1 & 1 & 0 & 1 & 4 & 2 & 3 & 0 & 0 & 3 & 1 & 0 \\
\hline 0 & 0 & $11 \%$ & $11 \%$ & $0 \%$ & $11 \%$ & $45 \%$ & $\begin{array}{l}22 \\
\%\end{array}$ & $100 \%$ & $0 \%$ & $0 \%$ & $100 \%$ & $100 \%$ & $0 \%$ \\
\hline
\end{tabular}

\section{Data Interpretation in IELF Faculty}

The distribution shows that most of the acts are expressive, $67 \%$ of which $45 \%$ dominated by the higher status and assertive $22 \%$ of which are equally distributed, which means that amongfemale interactions are more personal and emotional exchange than dominance competitions. The higher dominates the initiation and the follow up while the lower dominates the response, the same as those of UDF and IELF faculty. It is similar to the other faculties that the higher female manages, controls. It dominates the conversation by initiating and following up but softened by dominating the expressive acts (45\% vs. $11 \%$ ), and the lower supports and accommodates the higher by responding moves (100\%). This dominance of the higher in this conversation, by initiation and follow up moves, is accommodated by the higher by having much more expressive acts. It proves that higher female dominates the interaction, but it is softened by having more expressive acts.

\section{CONCLUSION}

Many studies of gender conversation strategy have been explored on crossgender asymmetrically, excluding the social status of the gender among the participants. The analysis of the symmetrical interaction in terms of gender shows that female-tofemale is more operational and observable to integrate the Birmingham Discourse Model with the consequential analysis of acts presented by Leech. It is an alternative way of studying the acts and moves in the conversational analysis. This analysis of the same gender, among females, intersected with their social status, in three functional topical units, demonstrates that the higher status the female participant is, the more initiations and directive acts will be, and the lower the status is, the more assertive acts and the more moves of responses will be. The higher female has strategies to dominate, manage, and control the conversation by making her listener do something, imitating, and following up the conversation. The lower status female shows her support, accommodation, togetherness by asserting, and responding. It implies that the strategies of Muslim 
females in the informal talk, the actual data of using language, are almost the same as the higher status male in formal crossgender conversation. The female and male choose the talk strategy based on whom they speak to (male or female), what situation takes place and their status. Then, the research to be made is the strategy of male-to-maleand cross-gender at informal conversation in different and wider coverage of areas and populations.

\section{REFERENCES}

Baker, P. (2008). Sexed Texts: Language, Gender, and Sexuality. Gender and Language, 7(2), 265-270.

Coates, J. (2004). Women, Men, and Language. London: Longman.

Eckert, P., \& Sally, M.G. (2003). Language and Gender. Cambridge: Cambridge University Press.

Edvardsson, M. (2007). Topic Shift and Initiation from a Gender Perspective: A study of Conversational Topic Shifts among Second Language Learners of English. Karlstad University. Retrieved from http://www.slis.india

Giyoto. (2013). Sociolinguistics Measure for Paternal Gender Dominance over Maternal One among Javanese Muslims. International Journal of Science and Research (IJSR), 2(3), 504510.

Giyoto, Novianni, A., \& Elen I. (2020). How does "to what gender and status one talks" govern the speaker's strategy in keeping on their conversation?. Journal of Language and linguistic Studies. 16(1), 166-184.

Gomaa, Y. A. (2015). Saudi Youth Slang Innovations: A Sociolinguistic Approach. International Journal of Linguistics and Communication, 3(2), 98-112.

Holmgreen, L.L. (2009). Metaphorically Speaking: Constructions of Gender and Career in the Danish Financial Sector. Gender and Language, 3(1), 1-32.

Johnson, S., \& Ensslin, A. (2007). But Her Language Skills Shifted the Family Dynamics Dramatically: Language, Gender and The Construction of Publics in Two British Newspapers. Gender and Language, 1(2), 229-254.

King, B. W. (2011). Language, Sexuality, and Place: the View From Cyberspace. In Gender and Language, 3(1), 1-30.

Lakoff, R. (1975). Language and Women's Place. New York: Harper and Row.

Leech, G. (1983). Principles of Pragmatics. New York: Cambridge University Press.

Nyamekye, E., \& Yarney, S. (2015). Social and Cultural Perceptions on Women's Education and Physical Embodiment on Their Ability to Wield Power over Men: The Yendi Experience in Northern Ghana. International Journal of Gender and Women's Studies, 3(2), 143-155.

Paulston, Bratt, C., Kiesling, S. F., \& Rangel, E. S. (2012). The Handbook of Intercultural Disco urse and Communication. Wiley Blackwell: West Sussex. 
Roman, Juhasz, C., \& Miller, C. (1994). The Women and Language Debate. USA: Rutgers University Press.

Santoso, B. (2012). The Influences of Javanese Culture in Power of Making Decisions in Indonesian Universities: Case Studies In Mm Programmes. Journal ofIndonesian Econo my and Business. 27, (2), 2012, 224-241

Sinclair, J. M. H., \& Coulthrad, R. M. (1975). Towards an Analysis of Discourse: English used by Teachers and Pupils. Oxford: Oxford University Press.

Thomberg, J. (2006). Boy and Girl Talk: A Sociolinguistic Study of International High School Students' Turn-Taking Patterns from a Gender Perspective. Retrieved June 11, 2011, from http://www.essays.se/essay/a27a593189/

Thorne, B., \& Henly, N. (1975). Difference and Dominance: An Overview of Language, Gender, and Society. In B. Thorne \& N. Henly (Eds.), Language and Sex Difference and Dominance (pp. 5-42). Rowley, MA: Newbury House.

Yavuz, A. (2015). Culture, Gender, Language, and Literature Relationship: 4th Year ELT Students' Perceptions of Female Issues in American and British Literature. International Journal of Language and Literature, 3(2), 25-34.

Yule, G. (2010). Textbook : The Study of Language. (F. Edition, Ed.). United Kingdom: Camb ridge University Press. 